UDC 821.161.2-1.09“192/194”

DOI $10.15421 / 462011$

\title{
FATHER FIGURE IN VASYL STUS' LYRICS
}

\section{O. Shaf}

Associate Professor, Candidate of Philological Sciences, Associate Professor of the Department of Ukrainian Literature,

Oles Honchar Dnipro National University olga_shaf@ua.fm orcid.org/0000 $00015692506 \mathrm{X}$

I. Pasko

Associate Professor, Candidate of Philological Sciences, Associate Professor of the Department of Ukrainian Literature

Oles Honchar Dnipro National University iryna_pasko@i.ua orcid.org/0000-0003-1925-2980

Introduction. Vasyl Stus, as Mykola Riabchuk argues, is "in the center of intensive patriotic myth-creating and iconization" due to mixing his literary talent, adherence to his civic principles, and self-sacrifice (Riabchuk, 1999: 14). Nevertheless, it would not be quite correct to assume that glorifying Stus in his heroic struggle against the totalitarianism would lessen his value as the poet. Moreover, it would be incorrect concerning the whole "stusology" that deals with the aesthetic and philosophic views of Vasyl Stus' lyric consciousness, the poetic features of his texts. Meanwhile, Stus' lyrics provide some space for new interpretations "in Freud's manner", as K. Moskalets somewhat condescendingly defines in his paper "Страсті по вітчизні. Лист до мандрівника на Схід" (A Lament for Motherland. The Letter to the Traveler to the East) (Moskalets, 1999), though he could not resist mentioning the attachment of the poet's lyrical self to his mother, whose sacralized vision is represented in the poem "Потоки" (Streams) and the other texts, and the lyrical self's confrontation with the cruel, vengeful God from "Час творчості" (The Time to Create).

In his article, K. Moskalets tries to "mitigate" the observation of the duality of Stus' lyrical self's attitude towards the "paternal figure" of God by appealing either to poetics, such as "reflections of Goethe-Prometheus fire" or to the philosophers of Gnosticism. K. Moskalets avoids putting a name on it, but he outlines accurately the essence of the psychosymptomatic attitude of the lyrical hero of V. Stus to the paternal figure - that is the Oedipus conflict. K. Moskalets assumes that in "the conditions of extreme life instability", the individual is prone to project his discomfort on society, "blaming it for the lack of self-balance". However, the cause and essence of those internal mechanisms that translate personal negativity into the image of a sinister god or "alienated" Ukraine remain unclear.

It is obvious that they appear in the deep layers of the psyche and manifest through the son's oedipal attitude towards his mother and father. While the number of scientists considers the role of mother figure in Stus' lyrics to be crucial, though hardly from the psychoanalytic perspective, the oedipal father figure often remains out of focus. The "theognosis" of V. Stus is covered in the studies of M. Balaklytskyi (2001), Yu. Bedryk (1993), K. Moskalets (1999), B. Rubchak (1999) and others, however, the artistic significance of father figure in his lyrics and mental mechanisms that generate the attitude to it are not quite explained.

Understanding the role of a father in the context of the oedipal son-and-father conflict reveals a slightly different meaning of Stus' poetic revelations and his ultimate creative goal. The goal of this article is to consider the specifics of the artistic presentation of the father figure in the lyrics of V. Stus, externalized in the autobiographical image of his father along with the images of the poet I. Svitlychny - the leader of Stus' art generation, totalitarian leaders such as J. Stalin and God. The tasks are as follows: to examine the psychobiographic base of son-and-father relations in 


\section{Ukrainian sense. 2020. ISSN 2313-4437}

lyrical reflections as well social, political, and cultural influences on the author's consciousness; outline the ways of artistic implementation of the positive and negative attitude of the lyrical self towards the paternal figure; expand the interpretive field of V. Stus' lyrics with the cognitive aspect of the lyrical self's perception as a sacrificial, prodigal and rebellious son.

Methods and methodology of investigation. The declared goals and objectives include the use of psychoanalytic methods, primarily Freudian psychoanalysis (the concept of the Oedipus complex), as well as analytical psychology (archetypes of Father and Son), psychobiography (the situation in the Stus family), and psychohistory (transformation of son's national identity through totalitarian pressure). Freudianism outlines the features of the masculine oedipal "scenario": the filial psycho complex of hostility and rivalry (anger, resentment, anxiety, fear, jealousy, envy) in combination with the strategy of identification with the paternal figure ("to be like a father", "to be instead of a father"), which leads to an ambivalent son's attitude towards it. This attitude is quite problematic to express in the lyrics due to self-censorship and a taboo imposed by patriarchal culture on the devaluation and criticism of parental authority.

Attempting to process the guilt for being hostile to his father, the author tends to positivize his image. Furthermore, the feeling of oedipal hostility is subdued under the pressure of fear of "castration" (retribution), as well as the need to identify with the father in order to establish the masculine status. Solidarity with the father helps to distance oneself from the mother in the final stage of the oedipal conflict. Inhibition of the normal course of the conflict then causes fixation in its separate phases, and hence mental regression, leading to neurosis. The latter often sublimated through creativity.

In V. Stus's lyrics, the mother figure has an active position, its conceptualization reveals the oedipal fixation on it, the inhibition of separation processes, and, as a consequence, identification with the father. As a result, his figure remains at the epicenter of the son's feelings of hostility, fear, and guilt. First of all, the direct expression of negative feelings towards the father, including the art, is taboo imposed by patriarchal culture with its moral imperative to bow to the father's authority, and secondly, it is mentally inhibited by the fear of fatherly revenge and the need to identify with him. The duality of the filial attitude to the paternal figure in V. Stus' lyrics activates the archetypes of either Good or Evil, Castrating Father, which are subsequently incarnated in the images of the poet's father, his friend and teacher I. Svitlychny, party leaders, and God. The psychobiographical situation of V. Stus, his shameful for his family imprisonment deepens his guilt, especially towards his father, whose figure symbolizes the Super-ego, which leads to positivization of his image in the author's consciousness and negativization of his self as an unworthy son. On the other hand, the repressed filial negativity to the paternal figure sublimates in the critical, exposing the image of the party leaders, further strengthened by the anti-colonial intentions of the author's consciousness. The same psychostimuli determine the ambivalent attitude of the lyrical self of $\mathrm{V}$. Stus to the figure of God - as to the Good and/ or the Evil Father.

Results and discussion. If compared to the frequency of appealing to the image of a mother, the image of father is quite peripheral in the lyrics of V. Stus, which does not mean it is psychoemotionally neutral or indicates its insignificance. The autobiographical image of the father appears in the single poem "Сто чорних псів прогавкало. Сто псів...” (One Hundred Black Dogs Barked. One Hundred Dogs...) (from the collection "Palimpsest"), filled with a deep sense of filial guilt caused by the death of the poet's father. V. Stus' confrontation with the blatant injustice of the camp authorities, which prevented him from seeing his father for the last time, probably exacerbated his pain and guilt expressed in poetry. Here, the image of his father is both tenderly diminished ("Мій хорий орлику!" that is how the lyrical self mentally addresses his father) and extended to a whole world, like God, like the conscience, Старечою ходою / із костуром - іще бриниш мені / всеобрієм. The lyrical self in the attempt to atone for the involuntary "sin" of dishonoring his father's name (the prisoner Vasyl Stus knows this), is ready to drink the cup of Christ from the Father's hands, so he says the biblical, Хай помине ия чаша! Але так, / як хочеш Ти. Не я. Перечекає / чи помине. In the image of mortally closed, frozen lips, either father's or son's, - Стули уста. Мороз / смертельних вінць ляга на них, мов іній, we read the readiness of 


\section{Ukrainian sense. 2020. ISSN 2313-4437}

the lyrical self to take on his father's death, to die for him to atone for his "sin". The image of the deceased father is metonymically concentrated in the image of his eyes as the embodiment of his reproach, Два дальніх ока. І один / твій погляд - геть усе збагнулий, which brings in the allusion to the God's all-seeing eye, and the son's conscience behind it. The motif of his father's death in this poetry of V. Stus is enveloped into the Cossack funeral ritual through the concepts of red kytaika (the funeral fabric), Cossack horse, folklore imagery, “козака несуть...", which implies the projection of the father's image into the plane of the Cossack past, his inspiration by the idea of national heroism. The situation when the son returns to his father to receive his last words of forgiveness metaphorically correlates with the biblical motive of the prodigal son, Це ти? Це я, твій блудний син, which is also based on the masculine oedipal psychosituation of "turning" from hostility to solidarity with his father. The final gesture of redemption made by the lyrical hero of V. Stus, Тулюсь живцем усім, усеньким / живием - до сірої щоки, however, does not bring him relief and does not save him from retribution - the death, because it fills the whole world - "земля посовгнулась" and "небо гробове". The lyrical subject's conscience tortures him for "the sin" not so much for shameful imprisonment as for the hostility to his father, which suddenly came true in the fact of his death. Conscience appears as a powerful self-destructive force, an instrument of "suicide", metaphorically embodied in poetry in the image of sinister black dogs,

З усіх усюд, усіх кутків

великих кулилось сто псів.

Мене в усі ловили очі.

Хто збавив нам віка, зурочив?

І гавкало сто чорних псів (Stus, 2009: 350).

The filial feelings of guilt and love are also projected on the "paternal" figure of Ivan Svitlychny in V. Stus' poem "Не можу я без посмішки Івана...” (“I Can’t Do Without Ivan's Smile..."). ${ }^{1}$ The arrest of I. Svitlychny in 1965 and the feelings it caused are artistically expressed in this poem. It might as well be perceived by the poet as a test - for his courage, his strength to stay faithful to himself and the common cause, despite the threat of arrest. All this is engraved in the роет, Коли тебе, коханий, покарають - / куди втечу від сорому й ганьби? The strategy here is to replace the contentious figure of the father with the authoritative figure of a teacher or a leader and directing identification aspirations to it - this kind of masculine mental tactic was described by Z. Freud (Freud, 2006: 493).

The filial hostility, as well as the refusal to serve, to obey the father figure (God, leader, etc.), is manifested through anti-totalitarian/ anti-imperial motives of V. Stus lyrics (especially from the collection "Веселий цвинтар" (Merry Cemetery)) and is directed at the USSR authorities, especially Joseph Stalin. His sinister paternal figure is recognizable behind the images of a "skilled cameraman", the "third one" who "starts a campaign for paradise" from "Вертеп" (Nativity Scene), a prompter from “Ця п’єса почалася вже давно...” (This Play Began a While Ago...), and so on. In the poem "Ось вам сонце, сказав чоловік з кокардою на кашкеті..." (Here Is the Sun for You, Said the Man with the Cockade on His Cap...), the figure of J. Stalin is encoded in the title. His "fatherhood" is expressed in his patronage over the human mass, as he endows it with "goods", with the life in the Soviet Union, but the nature of this happy life is ostentatious (not the sun, but a penny), the joy is false (“Щоб вам було радісно - вмикайте магнітофони, транзистори”), and the songs are censored, "дозволені цензурою для колективного співу." Even the heroic victory of the people in the war is just another "game",

Коли вам захочеться відпочити -

розучуйте цікаву гру про війну,

\footnotetext{
${ }^{1}$ The role of I. Svitlychny for V. Stus, a young poet, a stranger in the capital city, was in many aspects a paternal role. From the memoirs of V. Stus' friends and other biographical materials, it is known that a great role in his creative selfrealization played the meetings with like-minded people in I. Svitlychny's apartment, together with his advice and approval. In the "Таборовий зошит" (Camp Notebook) V. Stus records his vision of Ivan Svitlychny's coffin over Kyiv, similar to the "statue of Jesus Christ over Rome" (Record 9-10; quot. Stus, 2005: 342), which reveals the paternalistic quality of the image of a teacher and a friend in Stus' consciousness.
} 


\section{Ukrainian sense. 2020. ISSN 2313-4437}

уявіть, щчо опали вас вороги

і хочуть позбавити щасливого існування.

Словом, стріляйте, кидайтесь на амбразури,

падайте під танки.

The price for this "happy" life is imprisonment and death, hypocritically camouflaged in general patriotic uplift and enthusiasm,

Тільки не розбігайтесь, докинув він.

- Благодійнику наш,

кому хочеться тікати з раю, -

загукали ми в одне горло

вдивляючись в очі під кокардою,

схожі на дві крапельки ртуті.

The final portrait detail accumulates the threatening, deadly features of "a man with a cockade on a cap."

In the poem by V. Stus “Ця п'єса почалася вже давно..." (This Play Began a While Ago...) a similar picture of the Soviet world is unfolded - absurd, deceptive, artificial, and deadly. The "paternal" power in this world is allegedly absent ("a man with a cockade" is nowhere to be seen), however, its "invisible presence" (which supports the illusion of "Soviet power") is even more threatening for the lyrical narrator. This power is manifested through a particular metaphoric detail - the Polyphemus' еуе/ "око Поліфема угорi", which embodies the fear of parental malicious supervision. The exposure of the criminal power of the Evil Father in V. Stus' lyrics is dictated by his civic position, the anti-colonial "pathos" of his artistic thinking. At the same time, the conceptual "triangle" in his texts - the lyrical subject/ the hostile Evil Father/ the motherUkraine, who needs son's love and protection - restores the oedipal conflict, thus giving additional mental stimuli to the artistic realization of anti-totalitarian motives, meaning the legitimate from the perspective of the Super-ego and national self-consciousness (although not allowed by Soviet censorship) field of sublimation of oedipal hostility to the parent figure.

The oedipal evolution from the hostility and rebellion against the father to identification with him is extrapolated to religious discourse. The image of God, usually nourished by the introjected parental imago, embodies the Super-ego and demands self-restraint (obedience) and selfpunishment (remorse and shame) from the believer. The "drama" of the "son-father" relationship of the lyrical hero with God is relevant for the lyrics of V. Stus, especially the collection "Yac творчості" (Creative Time). It sublimates the artist's internal conflict between the fulfilled duty to mother-Ukraine because imprisonment is equivalent to a heroic "filial" feat, and "betrayal" of another maternal object - mother and wife, who are doomed to pain and suffering. The paternal figure also splits within this moral conflict: its malicious incarnation threatens to punish the lyrical self. In fact, him being "dead alive" in a prison situation is already a punishment from a sinister God (rather than a system that he uses as a tool). At the same time, the lyrical hero, who proved his masculinity by a heroic act, claims a reward from the God as a Good Father, he demands support from God as a sign of solidarity with him.

In the lyrics of V. Stus, the image of God as the embodied conscience creates the narrative intonations of reporting before Him, comparing one's own life with His will, it is especially evident in the poem "Я непомітно перейшов межу..." (I Crossed the Line Without Being Noticed...), as well as the search for the causes of God's wrath, І чим ти Бога прогнівив, / мій болю самобутній? ("Поглянув у німе вікно..." (I Looked in the Silent Window...)). Sometimes a powerful paternal figure is seen through the image of God - a source of strength and anger. This is what feeds the lyrical hero's needs for moral resistance and successful passing of the test,

Господи, гніву пречистого / Благаю - не май за зле. / Де не стоятиму - вистою (назва за наведеним рядком);

На всерозхресті люті і жаху, / На всепрозрінні смертного скрику / Дай мені, Боже, чесного шляху, / Дай мені, Боже, гордого лику! (“Уже Софія відструменіла...” (Sophia Has Already Flown Away...)); 


\section{Ukrainian sense. 2020. ISSN 2313-4437}

Боже, не літості - лютості, Боже, не ласки, а мсти, / Дай розірвати нам пута иі, / Ретязі иі рознести (“Трени М.Г. Чернишевського”, поезія IV (Laments of M. G. Chernyshevskyi, Poem IV)).

In fact, the situation of the test, which requires anger and rage - "the crossroads of rage and horror", "shackles" and "chains" in the quoted poems of V. Stus - correlates with the mythological (and initially - mental) "plot" of initiation ${ }^{2}$, following which, to become masculine, one must pass the test of death - a kind of "paternal" initiation to acquire the secret knowledge (that is, it is necessary to submit, to suppress filial ambitions in order to identify with the father). The initiating situation of the death test - a milestone in the formation of the masculine psyche - is superimposed on the anti-colonial / anti-totalitarian dissident practice of V. Stus, where the "test" means the open resistance to the system, leading to the removal of patriotic "son" from active life, hence, to his symbolic "death". Therefore, the paradoxical aspiration of V. Stus to such a fate, which is expressed in the following poems,

...добре, щзо не зуміла/ Мене од біди вберегти;

Хай і на смерть, а-вперед. / Благословенна хай буде та / Куля туга, щзо разить / Плоть.

The paternal figure who tests the lyrical hero of V. Stus is God. He gives strength to fight and can reward for your efforts, “Бог шепоче спрагло: Аз воздам!' (“Сосна із ночі випливла, як щогла..." (The Pine Tree Emerged Out Of The Night Like A Mast...)).

In V. Stus' poetry, God also initiates the trial of the lyrical hero, who in this case finds himself as the chosen one, Son of God, Ця Богом послана Голгота ("Як тихо на землі!" (So Quiet on Earth!)); ...вам на лоб поклав Господь свій світлий перст нищівний ("Трени М. Г. Чернишевського", вірш V (Laments of M. G. Chernyshevskyi, Poem V)). In the poem "Самотньо сновигає голос..." (Lonely Wanders the Voice...), the author artistically recreates the imaginary conversation of the lyrical hero with God, who tested him, “слав лихоліття, щоб до життя ти був воскрес"/ "praise the hardship, so you may be resurrected to life" so that he could realize that "над покари немає більшої цноти"/ "there is no greater virtue than punishment." In other words, he realized that the only true way is Christ's way of martyrdom, and the only life for him is the self-chosen suffering of a slow death for the sake of ideals (although, judging by the lyrical "document" of the poet's soul, this self-complacency did not seem to work very well). This interpretation makes perfect sense in the poem, "Гойдається вечора зламана віть..." (The Broken Twig of Evening Trembles...), - "Сподоб мене, Боже, високого краху!” This is the quintessence of Stus' mature worldview.

The deadly risk of the test sometimes provokes the confusion with punishment. The motif of God's punishment is artistically interpreted in V. Stus' lyrics as a fate that hangs upon his lyrical hero, which is at the same time a paradoxical manifestation of God's concern. The masochistic desire for punishment from the parent figure also compensates for the sadistic impulses directed at it, foreshadowing its actions,

...mи, Господи всевишній, / карай нас, многогрішних... (“І навалились дні...” ( And the Days Came Down...));

...а ти смертельним дрожем / нас, Господи, карай ("Гей, яром-долиною...” (Неу, Over the Valley...));

Карай мене, мій Боже. Слава Богу, / що зглянувся на мене. I- карай (:Нема кайданів, щоб твій дух здушили...” (There Are No Shackles to Tame Your Spirit));

Дай Боже хоч біди якої, / коли ні краю ні коня / i долі дай - та злої! злої! - / нехай донищує до пня! (“Стара людина, сопки давні...” (Old Man, Ancient Hills...)).

\footnotetext{
2 Synchronization of V. Stus' fate with the three-step paradigm of the behavior of a cultural hero (according to J. Campbell) - "separation from the everyday world, penetration into a source of some supernatural force and, finally, a life-asserting return." In fact, the "initiation" of the artist is noted by M. Ryabchuk, who defines its purpose and result (formulating them after J. Campbell), "to overcome the terrible aspect of father and to release from under his curse the vital energy, which will feed the world" (Ryabchuk, 1999: 14-19), that is to save the symbolic mother's essence from the Evil Father.
} 


\section{Ukrainian sense. 2020. ISSN 2313-4437}

The prospect of God's punishment stimulates an onslaught of hostility in V. Stus' lyrics. The unfortunate fate of the lyrical subject and the disharmony of the world he lives in are attributed to the God's will and thus provoke the discrediting of His image as cruel, vindictive, corrupt, and indifferent to people,

Господь живущих не прощэає ("Ми з теміні виходимо на світ..." (We Are Born Out Of Darkness...));

Господь нагородив/ божевіллям переселень, / конкурениією зла (“На однакові квадрати..." (On the Same Squares...)).

Бог / постав, як лютий бич $і$ можновладия (“Тюремних вечорів смертельні алкоголі...” (Deadly Alcohol Of Prison Evenings...));

...Добра / Сам Бог прелютий / був зичив, даючи ией хист / проклятий - віршувати / на власну голову (“Вік би не бачити й не чуть...” (I Wish I'll Never See Or Hear You Again...)).

In a number of poems by V. Stus, the lyrical self is obviously disappointed and offended by God, who in his imagination sows evil, suffering, and death instead of good,

Давно відгородився я від нього, / давно збагнув, щзо пруття заборон / поставлені благою дланню Бога; А той, на небеси, із нас сміється, / він, нас убивши, тільки й збереже (“Не квиль, нічна душе! Даремні зойки..." (Don’t Whine, My Nighttime Soul! Don't Cry In Vain...)). This attitude towards God reflects the aggression of the lyrical subject, which grows, exacerbating his conflict with the world.

The Devil, Lucifer, is the dark side of the Gnostic deity, emotionally charged with the archetypes of the Shadow, the Evil Father. In fact, both God and Devil are two aspects of the paternal figure, polarized in the mind of the lyrical hero to reduce the internal conflict between love and hostility towards the father. In religious, mythological, and, of course, artistic consciousness, the images of God and Devil often merge, restoring an ambivalent paternal origin. From this perspective, the identification of Lucifer with God in poetry of V. Stus seems to be justified, for example, in the following lines, ...ичі нестерпні дні благослови / одним ім'ям - Люципера чи Бога (“Ну й долечка! Прождати на життя...” (Such a Fate! Been Waiting All Live Long...)) On the other hand, when such an identification happens, it ensues the demonization of the image of God: in the absurd world, He also becomes the devil.

In some of V. Stus' poems, the discrediting of God correlates with the motives of selfhumiliation and the punishment is considered well-deserved, ...тобі, потворі, спересердя / добру мову й розум одібрав (“Жовтий місяць, а ще вище - крик твій...” (Yellow Moon and the Scream of Yours Above It...)), and often accompanied with the expressions of anger and incapability to reproach God,

О, Боже праведний, важка докука-

сліпорожденним розумом збагнуть:

ти в цьому світі - лиш кавалок муки,

отерплий і розріджений, мов ртуть (“Отак живу: як мавпа серед мавп...” (This Is How I Live: a Monkey Among the Monkeys...)).

Later, in the poem "I не розмерз. І не відтерпнув..." (I Did Not Thaw. I Did Not Unwind...) the image of a chunk (кавалок) emerges again as a metaphorical characteristic of the author's destructive self and again it is mentioned in connection with inability to comprehend God's plan,

Це ж ти мене береш,

немов шматок невироблений глини

і місиш, мнеш, і пальиями всіма

формуєш образ, щоб не задарма

іще один кавалок з України

сподобивсь твердi.

A chunk is a shapeless mass that resembles a product of rejection, so it has rather derogatory 


\section{Ukrainian sense. 2020. ISSN 2313-4437}

connotations in relation to the subject ${ }^{3}$. Despair, frustration, self-humiliation, directed at the author's Self, are, in fact, addressed to God as a careless Creator, as a "false father."

Vasyl Stus' "dramatic" confrontation with his father was lyrically documented within the walls of the Kyiv pre-trial detention center, it is filled to the fullest with love and pain, fear and anger, remorse and hatred. For example, in the poem "Упасти Господові в ноги..." (Fall to the Lord's Feet...), where a choice is made between two "son" scenarios - obedience to God ("father") and resistance to Him,

\section{Упасти Господові в ноги \\ і відмолити всі гріхи, \\ і попалити всі дороги, \\ i загубити всі шляхи. \\ Не діжде, проклятий, не діжде. \\ Я стану з Господом на прю!..}

The "scenario" of the repentant "prodigal son", although considered in some texts by V. Stus as possible, is rejected here. His lyrical hero chooses Lucifer's "scenario" 4 of life-long confrontation, because this is the only way for him to complete masculine identification, to become a father, to be instead of a father, to take his place. This oedipal mechanism is manifested in the text almost literally, in particular, through the intention of the lyrical subject, ... вирву з посмерку зорю / і почеплю ї̈ на небо: / хай світить, бісова, як слід!, - which translates his desire to possess God's ("father's") place of the Creator of the world, to do the same as He did, but in his own way. The lyrical hero desires to gain immortality through the descendants, their memory, to build his own genealogical line, to immortalize himself,

...та, може, з правнуків діждуся -
хтось піде й піде по сліду,
і розпізнає серед снігу
серед глибокого мій хрест,
і може зіб'є з нього кригу,
аби, померлий, я воскрес
і пробудився жити знову..., -

which also expresses his serious claim for paternal status. Therefore, the theme of relations with God as an ambivalent parental figure, concentrated mainly in the mature lyrics of V. Stus, written under the influence of serious life trials, has, in our opinion, no direct connection with religion, but is dictated by mental oedipal "drama" (rehabilitation and/ or condemnation of the father figure), whose lyrical sublimation became urgent in the light of the masculine act - open resistance to the totalitarian system. The borderline situation in which the poet found himself during the days of imprisonment, artistically refracted in his work, caused the existential aggravation of the dilemmas of life and death, peace, reconciliation and suffering, and struggle. All these dilemmas artistically "fit" into the God-fighting/ God-seeking discourse of the artist's lyrics, and are executed in three main "scenarios": 1) "Christ" (the lyrical hero is chosen by God for the heroic selfsacrifice, he awaits the tribute, his position is active, he identifies with the loving God/ Father in the sensory spectrum of gratitude, hope); 2) "prodigal son" (in the end, the lyrical hero repents of godfighting, his conquest after a failed resistance is overshadowed by self-depreciation and redemption); 3) "Lucifer" (lyrical hero discredits God, exposes his malice from the standpoint of resistance and search for an alternative parental identity in the emotional spectrum of hatred, contempt, anger, resentment, disappointment). In the lyrics of V. Stus, these basic "scenarios" are activated simultaneously, causing much confusion for the scientists, who research the theme of God in his work.

Conclusions. The father figure in Vasyl Stus' poetry is represented scarcely in the

\footnotetext{
${ }^{3}$ Ye. Sverstiuk interprets the content of this poem quite differently - as "a self-study, when a person happens to be alone with God" (Sverstiuk, 1993).

4 "Luciferic action" in the poetry of V. Stus, imitation of the Lucifer's path by the lyrical hero is described by M. Balaklytskyi (Balaklytskyi, 2001: 98).
} 


\section{Ukrainian sense. 2020. ISSN 2313-4437}

autobiographical image of his father and the image of his teacher and friend I. Svitlychny, more extensively in the images of party members and the "leader of the nations", and on a large scale in the image of God. It is filled with the archetypes of the Good and Evil Father and translates the oedipal filial complex. On the one hand, it is possible to "rationally" explain the lyrical subject's attitude to all the "reincarnations" of the paternal figure - the autobiographical experiences of remorse for the deceased father, dissident resistance to the Soviet party nomenclature, and so on, but the range of feelings - from tenderness and remorse to hatred and wrath, and most importantly, the intensity of their expression clearly restores the oedipal psychomatrix in V. Stus' lyrics. Displacing the hostility to the father either "obscures" his image, leaves him in the shadows, or intensifies the piety towards his figure and sharpens the feeling of guilt towards him. The fear of violating official ideological and cultural norms, as well as moral self-censorship work likewise. The dissident text, on the other hand, releases a subdued confrontation with the father. The borderline life situation determines the full-fledged reincarnation of the oedipal experience in V. Stus' lyrics and actualizes the discourse of God-fighting/ God-seeking, which "logic" lies in the search for paternal identification and at the same time in resistance to it.

\section{REFERENCES}

Balaklytskyi, M. (2001). "Nova relihiinist" Vasylia Stusa ["New Religiosity" of Vasyl Stus]. Aktualni problemy ukrainskoi literatury i folklore - Relevant problems of Ukrainian literature and folklore: Materials of the 2nd All-Ukrainian Scientific Conference, 95-100 [in Ukrainian].

Bedryk, Yu. (1993). Vasyl Stus: problema spryimannia [Vasyl Stus: the problem of perception]. Kyiv: Fotovideoservis [in Ukrainian].

Freud, Z. (2006). Lectures on Introduction to Psychoanalysis and the New Cycle. In: Freud, Z. Sobranije sochinenii v 10-ti tomakh [Collection of works in 10 volumes]. (Vol. 1.) Moscow: Ph "Firm STD" [in Russian].

Moskalets, K. (1999). Strasti po vitchyzni. Lyst do mandrivnyka na Skhid [A Lament for Motherland. The Letter to the Traveler to the East]. Krytyka - Critics, 6 (20), 4-14.

Riabchuk, M. (1999). "Nebizh Rilke" i "syn Tarasa" ["Rilke's nephew" and "son of Taras"]. Krytyka-Critics, 6 (20), 14-19 [in Ukrainian].

Shaf, O. (2018). Liryka Vasylia Symonenka, Vasylia Stusa, Tarasa Melnychuka: hendernopsykholohichni dom,inanty [Lyrics of Vasyl Symonenko, Vasyl Stus, Taras Melnychuk: gender and psychological dominants]. Bibliotechka "Dyvoslova" - Dyvoslovo's Library, 1, 60 [in Ukrainian].

Stus, D. (2005). Vasyl Stus: zhyttia yak tvorchist [Vasyl Stus: life as creativity]. Kyiv: Fakt [in Ukrainian].

Stus, V. (2009). Palimpsesty (Naipovnishyi nezavershenyi) [Palimpsesty (The most complete unfinished edition)]. In: Zibrannia tvoriv: u 12 tomakh - Collection of works in 12 volumes. (Vol. 5). Kyiv: Fakt [in Ukrainian].

Sverstiuk, Ye. (1993). Vasyl Stus - letiucha zirka ukrainskoi literatury [Vasyl Stus - a shooting star of Ukrainian literature]. Kyiv: Tovarystvo "Znannia” Ukrajiny [in Ukrainian].

\section{Анотація}

Постановка проблеми. Поза увагою літературознавчого вивчення творчості Василя Стуса лишається концептуальність виражених у його поезіях психічних реакиій ліричного героя на ті реалї світу, щуо змістовно корелюють з фігурами батька, матері. Інтимноособистісний смисл відбитих у творах В. Стуса синівсько-батьківських взаємин (хоча вони художньо екстраполюються на широке коло життєвих явищ, визначають громадянськопатріотичні, релігійні почуття) здебільшого не вписується в “іонізований” образ поета, водночас ией смисл важслиий для розуміння світовідчуттєвих засад авторської свідомості, розширює інтерпретаційний план лірики В. Стуса.

Мета статті- розглянути специфріку художньої презентаиї в ліриці В. Стуса батьківської фігури, експлікованої в автобіографічному образі батька, в образах тоталітарних вождів та Бога. 


\section{Ukrainian sense. 2020. ISSN 2313-4437}

Методи дослідження. Проблема вивчення рефлектувальної свідомості ци пропущеного крізь іï призму світу дотична до антропологічних защікавлень літературознавства. Висвітлення генеративних механізмів иієї свідомості зумовлює звернення до психоаналізу (фройдизму, аналітичної психології, психобіографії, психоісторії). Специфіку художнього вираження конщептуального для ліричної свідомості В. Стуса ставлення до батьківської фігури досліджено за допомогою традииійних літературознавчих методів, серед яких найпродуктивніші образно-мотивний, структурносемантичний.

Основні результати дослідження. У ліриці В. Стуса до батьківської фігури виражене неоднозначне ставлення, референтне синівській едиповій психосимптоматиці. Автобіографічний образ батька на порозі смерті, наснажений почуттями синівської любові, жалю, розкаяння фігурує лише в поезії В. Стуса "Сто чорних псів прогавкало. Сто псів...". Любовно-шанобливі синівські почуття екстраполюються в поезї̈ В. Стуса "Не можуя я без посмішки Івана...” на образ його вчителя й друга I. Світличного. Різко негативне ставлення транслюється в поезї В. Стуса до тоталітарних вождів, передусім Й. Сталіна, чия фігура наснажується архетипом Лихого Батька. У поезіях такого змісту синівський батькоборчий негатив корелюе з антиколоніальною позицією мития-дисидента. Багатопланово представлений у ліриці В. Стуса ("Час творчості", "Палімпсести") смисловий план взаємин ліричного Я з Богом, у якому зреалізовано такі варіанти едипового “сценарію”, як підкорення батьківській фігурі Бога (шлях Христа та “блудного сина”) або опір Його волі та протистояння з Ним (Люциферів шлях).

Висновки i перспективи. Батьківська фігура в ліриці В. Стуса має смислову перспективу на автобіографічному, громадянському, релігійному рівнях ліричної самопрезентації. У вираженому до неї синівському ставленні ліричного Я експлікується едипова психоматриия, яка координується $з$ морально-етичними, патріотичними й релігійними установками. Психоаналітичне прочитання поезї $B$. Стуса розширюе ї̈ інтерпретаційні горизонти.

Ключові слова: лірика Василя Стуса, лірична свідомість, батьківська фігура, едипів комплекс, синівсько-батьківські взаємини.

\section{Abstract}

Background. Literary study of Vasyl Stus's lyrics doesn't deal with conceptual meaning of the lyric's hero psychical reactions to the realities of the world correlated with father's and mother's figures. Intimate and personal sense of relationship between a son and a father depicted in Vasyl Stus's poems extrapolates on the different things, defines civil, patriotic and religious feelings. Though this sense destroys the "iconic" image of the poet it discovers worldview's grounds of the author's consciousness, expends the opportunities to the interpretation.

Purpose. The specificity of art presentation of the father's figure embodied in autobiographic image of the father, in the images of the totalitarian leaders and God in Vasyl Stus's lyrics is studied.

Methods. The question of the reflecting consciousness in lyrics concerns the field of the anthropological literary. The methodical complex of psychoanalysis is effective for the coverage of the mechanisms of the author's consciousness's emergence. The basic literary methods such as analysis of images and motives, structural and semantic analysis need to discover art representation of relationship between a son and a father in Vasyl Stus's lyrics.

Results. Ambiguous relationship with the father's figure according to the son's Oedipus complex is expressed in Vasyl Stus's lyrics. Autobiographic image of the dead father complemented by son's feelings of love, sad, shame, remorse is presented in the Stus's poem "One hundred black dogs have barked. One hundred dogs...". Son's feelings of love and respect are extrapolated for the image of Stus's friend I. Svitlychniy in the poem "I can't do without Ivan's smile...". It's remarkable, that sharply negative lyric hero's attitude to totalitarian leaders, particularly to Yo. Stalin, is implemented within the Cruel Father archetype and very often is transformed into 


\section{Ukrainian sense. 2020. ISSN 2313-4437}

anti-colonial, dissident motives in Stus's poems. Ambiguous relationship between lyric hero and God in Stus's collections "Creativity Time", "Palimpsests" demonstrates such type of son's Oedipus complex as Christ Way and Prodigal Son's Way leaded to submit to God-as-father or Lucifer's Way opposing His Power.

Discussion. Father's figure expresses wide autobiographic, civil, religious meaning in Vasyl Stus's lyrics. Ambiguous son - father relationship bases on the Oedipus complex, archetypes Father and Son and correlates with moral and ethic, patriotic and religious believes of the author's consciousness. Psychoanalytic view on Vasyl Stus's lyrics expends its interpretative field.

Keywords: Vasyl Stus's lyrics, lyric consciousness, figure of a father, Oedipus complex, son-father relationship. 